\title{
KONDISI OPTIMUM PROSES KEMPA PANAS DALAM PEMBUATAN PAPAN PARTIKEL DENGAN PEREKAT KITOSAN
}

\author{
Optimum Condition of the Hot-Pressing Process for Producing Particleboards using Chitosan Adhesive \\ Lestian Lindangan, Beta Putranto, Suhasman, Agussalim ${ }^{\bowtie}$ \\ Laboratorium Pemanfaatan dan Pengolahan Hasil Hutan, Fakultas Kehutanan, Universitas Hasanuddin, Makassar \\ ${ }^{\square}$ corresponding author: agussalim.madjid@yahoo.co.id
}

\begin{abstract}
Shrimp skin contains chitin that is the second largest biopolymer after cellulose. The chitin can be isolated to produce chitosan. Chitosan is a natural adhesive that can be applied in producing particleboards to substitute formaldehyde-based adhesives. The purpose of this study was to analyze the hot-pressing condition in term of temperature and pressing time on the physical and mechanical properties of the particleboards produced by using chitosan as adhesives. The particleboards were made with the size of $25 \times 25 \times 0.7 \mathrm{~cm}$ and target density of $0.75 \mathrm{~g} / \mathrm{cm}^{3}$. The particleboards were produced using different temperatures $\left(160^{\circ} \mathrm{C}, 180^{\circ} \mathrm{C}\right.$, and $\left.200^{\circ} \mathrm{C}\right)$ and pressing times $(9,12$, and 15 minutes). The results showed that the chitosan produced met the standards, and temperature and compression time had a significant interaction effect on the thickness swelling and modulus of elasticity. The optimum combination of temperature and pressing time is $180^{\circ} \mathrm{C}$ and 12 minutes, respectively. The produced boards have the characteristics of moisture content $12.2 \%$, density 0.81 , water absorption $84.47 \%$, thickness swelling $19.73 \%$, modulus of rupture $143.36 \mathrm{~kg} / \mathrm{cm}^{2}$, modulus of elasticity $23,367 \mathrm{~kg} / \mathrm{cm}^{2}$, and internal bonding $9.03 \mathrm{~kg} / \mathrm{cm}^{2}$.
\end{abstract}

Key words: chitosan, particle board, temperature and pressing time, hot press

\section{A. PENDAHULUAN}

Pengolahan kayu terkadang menghasilkan limbah yang cukup banyak. Limbah hasil gergajian akan dibuang begitu saja dan akan mencemari lingkungan. Padahal limbah tersebut dapat diolah lebih lanjut sehingga lebih bermanfaat dengan teknologi pengolahan kayu menjadi produk kayu non solid. Salah satu teknologi pengolahan kayu yang saat ini sedang berkembang adalah papan partikel. Papan partikel dibuat untuk memenuhi kebutuhan papan di Indonesia serta diekspor ke luar negeri.

Sebagian besar industri pengolahan papan partikel masih menggunakan perekat sintesis yang banyak mengandung formaldehida. Emisi formaldehida dapat mengganggu kesehatan dan juga lingkungan. Senyawa formaldehida dapat menyebabkan kanker, iritasi pada mata, dan kerongkongan serta gangguan pernapasan (Roffael, 1993). Selain itu, bahan dasar dari pembuatan perekat berbasis formaldehida adalah minyak bumi. Minyak bumi adalah sumber daya yang tidak terbarukan dan suatu saat akan habis. Oleh karena itu, dikembangkan perekat alami sebagai pengikat partikel kayu dalam pembuatan papan partikel, salah satnya adalah kitosan

Kitosan adalah salah satu perekat alami yang dapat diperoleh dari hewan berkulit luar golongan crustaceae seperti udang, lobster, dan kepiting (Kusumaningsih, 2004). Salah satu bahan dari kitosan yang cukup melimpah dan hanya menjadi limbah adalah kulit udang. Kulit udang sebagai bahan baku pembuatan kitosan yang selalu tersedia dan dapat diperbaharui sangat menjanjikan sebagai perekat papan partikel. Sebagai perekat yang belum dikembangkan lebih jauh, maka kitosan perlu dilakukan penelitian lebih jauh untuk memaksimalkan penggunannya. Papan partikel yang menggunakan perekat kitosan telah memenuhi standar JIS sehingga sangat layak dikembangkan seperti perekat alami yang lain. Selain itu, kitosan merupakan polimer kedua terbanyak setelah selulosa sehingga bahan baku pembuatannya tidak akan berkekurangan.

Pengaplikasian kitosan dibutuhkan bantuan kempa panas untuk mematangkan perekat. Perlunya optimalisasi pproses pengempaan ini sangat diperlukan untuk efesiensi energi dan biaya serta efektifitas kualitas serta kuantitas papan yang dihasilkan. Oleh karena itu, penelitian ini berfokus pada optimasi proses pengempaan papan partikel.

\section{B. METODE}

Penelitian ini menggunakan limbah kulit udang vaname (Litopenaeus vannamei) yang akan diolah menjadi perekat. Sementara, partikel kayu berasal dari jenis kayu sengon (Paraserianthes falcataria). 


\section{Preparasi Perekat Kitosan}

Limbah kulit udang dibersihkan dari sisa-sisa daging udang dan kotoran yang masih menempel. Kemudian kulit udang dikeringkan secara alami di bawah sinar matahari. Setelah kering, kulit udang digiling menggunakan hammer mill agar diperoleh serbuk kulit udang. Selanjutnya, proses pembuatan kitosan mengikuti metode Agustina et al., (2015) yang dimodifikasi. Kitosan diproduksi dalam tiga tahap, yakni demineralisasi, deproteinasi, dan deasetilasi. Tahap demineralisasi dilakukan dengan cara mencampur serbuk kulit udang dan larutan $\mathrm{HCl} 1 \mathrm{M}$ dengan perbandingan 1:15 (b/v). Campuran tersebut selanjutnya dipanaskan pada suhu $70^{\circ} \mathrm{C}$ selama 4 jam dan diaduk setiap 10 menit.

Residu kulit udang dari tahap pertama tersebut selanjutnya dideproteinasi untuk memperoleh kitin. Pada tahap ini, residu dicampur dengan $\mathrm{NaOH} 3,5 \%$ dengan perbandingan 1:10 (b/v). Campuran ini juga dipanaskan pada suhu $70^{\circ} \mathrm{C}$ selama 4 jam dan diaduk setiap 10 menit. Kitin yang diperoleh selanjutnya dideasetilasi dengan cara melarutkan kitin pada $\mathrm{NaOH} 60 \%$ dengan perbandingan 1:20 (b/v). Campuran tersebut dipanaskan pada suhu $110^{\circ} \mathrm{C}$ selama 4 jam dan diaduk setiap 10 menit. Kitosan yang diperoleh dijemur di bawah sinar matahari hingga kering. Formulasi perekat kitosan dibuat dengan cara melarutkan serbuk kitosan dengan pelarut asam asetat $\mathrm{CH}_{3} \mathrm{COOH}$ pada konsentrasi $0,5 \%$ dengan perbandingan $1: 5(\mathrm{~b} / \mathrm{v})$.

\section{Karakterisasi Kitosan}

Karakterisasi kitosan dilakukan menurut Standar Protan Laboratory yang meliputi: warna, rendemen transformasi kitin menjadi kitosan, kadar air, kelarutan, viskositas dan derajat deasetilasi.

\section{Rendemen}

Rendemen dihitung di setiap tahapan proses pembuatan kitosan, (rendemen tahap demineralisasi, deproteinasi, dan deasetilasi), dan juga rendemen dari kulit udang sampai menjadi kitosan dengan menggunakan persamaan (1).

Rendemen (\%) $=\frac{\text { Output }}{\text { Input }} \times 100$

Keterangan: output adalah berat akhir sampel (g); dan input adalah berat awal sampel $(\mathrm{g})$

\section{Kelarutan Kitosan}

Kelarutan kitosan ditentukan dengan melarutkan $2 \mathrm{~g}$ kitosan ke dalam asam asetat konsentrasi $2 \%$ dengan perbandingan 1:100 (b/v). Kemudian sampel disaring menggunakan kertas saring dan dipanaskan pada suhu $100^{\circ} \mathrm{C}$ selama 1-2 jam. Kelarutan kitosan dihitung dengan persamaan (2).
Kelarutan $(\%)=\frac{\mathrm{B} 0-\mathrm{B} 1}{\mathrm{~B} 0} \times 100$

Keterangan: B0 adalah berat awal sampel (g); dan B1 adalah berat kering sampel $(\mathrm{g})$, diperoleh dari berat contoh uji setelah dikeringkan dalam oven sampai didapatkan berat konstan.

\section{Viskositas}

Pengujian viskositas kitosan dilakukan menggunakan alat Brookfield Viscometer. Pengukuran dilakukan dengan terlebih dahulu melarutkan kitosan $1 \%$ kitosan ke dalam asam asetat konsentrasi $1 \%$ dengan perbandingan 1:100 (b/v). Selain itu, perekat kitosan yang telah diformulasikan juga diukur viskositasnya.

\section{Derajat Deasetilasi Kitosan}

Derajat deasetilasi ditunjukkan oleh nilai $\mathrm{N}$ deasetilasi yang dihitung berdasarkan serapan pada frekuensi $1.655 \mathrm{~cm}^{-1}$ dan $3.450 \mathrm{~cm}^{-1}$. Derajat $\mathrm{N}$-deasetilasi dihitung menggunakan persamaan (3).

$\mathrm{A}=\left(1-\left(\frac{A 1655}{A 3450} X \frac{1}{1.33}\right)\right) \times 100 \%$

Keterangan: $A$ adalah absorbansi yang diperoleh dari log (P0/P); $\mathrm{A}_{1655}$ adalah absorbansi pada panjang gelombang $1.655 \mathrm{~cm}^{-1}$ untuk serapan asetamida; dan $A_{3450}$ adalah absorbansi pada panjang gelombang $3.450 \mathrm{~cm}^{-1}$ untuk serapan $\mathrm{OH}$.

\section{Pembuatan Papan Partikel}

Kayu sengon ditatal dan digiling menggunakan hammer mill untuk memperoleh partikel. Partikel tersebut dikeringkan sampai mencapai kadar air sekitar 4\%. Proporsi ukuran partikel diamati dengan menggunakan enam saringan, yaitu 6/9 (lolos 6 mesh dan tertahan 9 mesh), 9/12, 12/22, 22/40, 40/60, 60/80 dan lolos 80 mesh secara berturut-turut adalah $1,12 \% ; 26,15 \% ; 43,85 \%$; 13,69\%; 9,27\%; 2,93\%; dan 2,99\%.

Papan partikel dibuat dengan mencampur partikel dan perekat dengan jumlah perekat adalah $10 \%$ dari berat partikel kering tanur. Papan berukuran $25 \mathrm{~cm} \times 25 \mathrm{~cm} \times$ $0,7 \mathrm{~cm}$ dibuat dengan kombinasi suhu dan lama kempa yang bervariasi. Suhu kempa terdiri dari $160^{\circ} \mathrm{C}, 180^{\circ} \mathrm{C}$ dan $200^{\circ} \mathrm{C}$ sedangkan lama kempa adalah 9, 12 dan 15 menit. Kerapatan sasaran dan tekanan kempa masingmasing adalah $0,75 \mathrm{~kg} / \mathrm{cm}^{3}$ dan $25 \mathrm{~kg} / \mathrm{cm}^{2}$. Selanjutnya, papan dikondisikan pada suhu ruangan selama 14 hari.

Pengujian sifat fisik dan mekanis papan dilakukan dengan mengacu JIS A 5908-2003. Sifat fisik yang diuji yaitu kerapatan, kadar air, pengembangan tebal, dan daya serap air, sedangkan sifat mekanis yaitu modulus elastisitas (MOE), keteguhan patah (MOR) dan keteguhan rekat internal (IB). 


\section{Analisis Data}

Semua data yang diperoleh dalam penelitian ini dianalisis secara deskriptif dan disajikan dalam bentuk tabel atau grafik.

\section{HASIL DAN PEMBAHASAN}

\section{Karakteristik Kitosan}

\section{Rendemen}

Rendemen merupakan hasil yang diperoleh dari proses pembuatan kitosan. Pembuatan kitosan melalui tiga tahap di mana setiap tahapan menghasilkan rendemen yang berbeda-beda. Proses pembuatan kitosan dimulai dari penghilangan mineral dalam kulit udang yang biasa disebut proses demineralisasi. Rendemen yang dihasilkan pada proses demineralisasi sebesar $41,2 \%$.

Setelah diperoleh kulit udang yang bebas mineral dilanjutkan dengan proses deproteinasi yaitu penghilangan kandungan protein. Proses deprtoteinasi digunakan larutan basa kuat yaitu $\mathrm{NaOH}$. Serbuk dan larutan dicampur kemudian diapanaskan untuk mempercepat proses pengikatan ujung rantai protein dengan $\mathrm{NaOH}$ (Agustina et al., 2015). Reaksi yang terjadi ditandai dengan sedikit gelembung dan larutan menjadi mengental dan berwarna kemerahan yang dapat dilihat secara langsung selama proses deproteinasi berlangsung (Dompeipen et al., 2016). Rendemen pada proses ini yaitu sebesar $78,8 \%$.

Kitin yang diperoleh dibersihkan dengan air bersih hingga $\mathrm{pH}$ netral. Selanjutnya kitin diisolasi untuk memperoleh senyawa kitosan melalui reaksi deasetilasi. Proses deasetilasi bertujuan untuk mengubah gugus asetil menjadi gugus amina dengan penambahan basa kuat. Rendemen kitosan yang diperoleh adalah $76,6 \%$.

Rendemen kitin yang diperoleh dari serbuk kulit udang hingga menjadi kitin adalah $32 \%$. Hasil ini hampir sama dengan yang diperoleh pada penelitian Agustina et al. (2015) yaitu $36,76 \%$. Dengan demikian diperoleh rendemen kitosan sebesar 25\% mulai dari kulit udang hingga menjadi kitosan. Kitosan yang diperoleh berwarna putih dimana memenuhi standar.

\section{Viskositas dan Kelarutan}

Kitosan yang dihasilkan memiliki viskkositas yang rendah dibandingkan dengan Standar Protan Laboratory yaitu 88,9 cP atau kurang dari $200 \mathrm{cP}$. Besarnya nilai viskositas dalam pengaplikasian kitosan berbeda-beda. Misalnya dalam bidang farmasi dibutuhkan viskositas yang rendah (Saputro et al., 2016).

Hasil pengujian kitosan yang diperoleh menunjukkan bahwa kitosan larut dalam asam asetat $2 \%$ dan sesuai dengan Standar Protan Laboratory dengan warna larutan yang bening atau tidak berwarna. Kitosan yang bermuatan positif menyebabkan dapat larut di dalam larutan asam organik seperti asam asetat maupun asam formiat. Mutu kitosan dapat dilihat dari larut tidaknya dalam larutan asam. Semakin tinggi kelarutannya, semakin baik pula mutu kitosan yang dihasilkan (Agustina et al., 2015). Kelarutan kitosan dipengaruhi oleh lamanya proses pada saat deasetilasi dan suhu yang digunakan, banyaknya larutan $\mathrm{NaOH}$ dan serbuk kitin yang digunakan, serta ukuran serbuk kitosan yang digunakan (Hossain \& Iqbal, 2014).

\section{Derajat Deasetilasi}

Derajat deasetilasi kitosan yang dihasilkan masih cukup rendah yaitu $73 \%$, meskipun nilai tersebut sebenarnya telah memenuhi Standar Protan Laboratory yang mensyaratkan derajat deasetilasi kitosan minimal $70 \%$. Sementara itu, kitosan terdeasetilasi sempurna ketika derajat deasetilasinya di atas 90\%. Besarnya derajat deasetilasi kitosan masih bergantung pada penggunaannya. Masih rendahnya derajat deasetilasi kitosan yang dihasilkan kemungkinan karena proses pengadukan dan suhu pemanasan yang digunakan serta habitat atau pemeliharaan udang yang digunakan (Agustina et al., 2010).

Tabel 1. Rendemen dan karakteristik kitosan

\begin{tabular}{llll}
\multicolumn{1}{c}{ Parameter } & \multicolumn{1}{c}{$\begin{array}{c}\text { Nilai Standar } \\
\text { Protan Laboratory }\end{array}$} & $\begin{array}{c}\text { Kitosan Kulit Udang } \\
\text { Vemane }\end{array}$ & Keterangan \\
\hline Rendemen (\%) & & 41 & \\
a. Serbuk kulit udang (KU)- demineralisasi & - & 77 & - \\
b. Demineralisasi-deproteinasi (kitin) & & 79 & \\
$\begin{array}{l}\text { c. Deproteinasi-deasetilasi (kitosan) } \\
\text { d. Serbuk KU-kitosan }\end{array}$ & & 25 & \\
Viskositas (cP) & $<200$ & & Rendah \\
a. Rendah & $200-799$ & 88,9 & \\
b. Medium & $800-2.000$ & & Memenuhi \\
c. Tinggi & $>2000$ & & Memenuhi \\
d. Sangat tinggi & Larut & Larut & Memenuhi \\
Kelarutan dalam asam asetat 2\% & Jernih & Jernih & \\
Warna larutan & $\geq 70$ & 73 & \\
Derajat deasetilasi (\%) & & & \\
\hline
\end{tabular}


Hilangnya gugus asetil dinamakan derajat deasetilasi. Kualitas kitosan dapat juga diketahui melalui besarnya derajat deasetilasi. Semakin tinggi derajat deasetilasi semakin baik ula kualitas kitosan yang dihasilkan. Munculnya gugus $\mathrm{C}=0$ pada bilangan gelombang $1.680-1.660 \mathrm{~cm}^{-1}$ menandakan masih ada atau telah berkurangnya gugus asetil pada kitosan.

\section{Viskositas Perekat}

Konsentrasi asam asetat yang digunakan untuk melarutkan kitosan adalah 0,5\%. Berdasarkan hasil pengujian dengan menggunakn asam asetat 0,5\% diperoleh viskositas $7 \mathrm{cP}$. Konsentrasi pelarut yang cukup rendah memudahkan proses pencampuran perekat dan partikel kayu karena viskositas yang lebih rendah.

\section{Karakteristik Papan Partikel}

\section{Kadar Air}

Kadar air merupakan kandungan air yang terdapat didalam papan partikel. Hasil pengujian kadar air papan berkisar antara 11,9\%-15,8\%. Hubungan antara suhu dan waktu pengempaan papan dapat dilihat dari Gambar 1

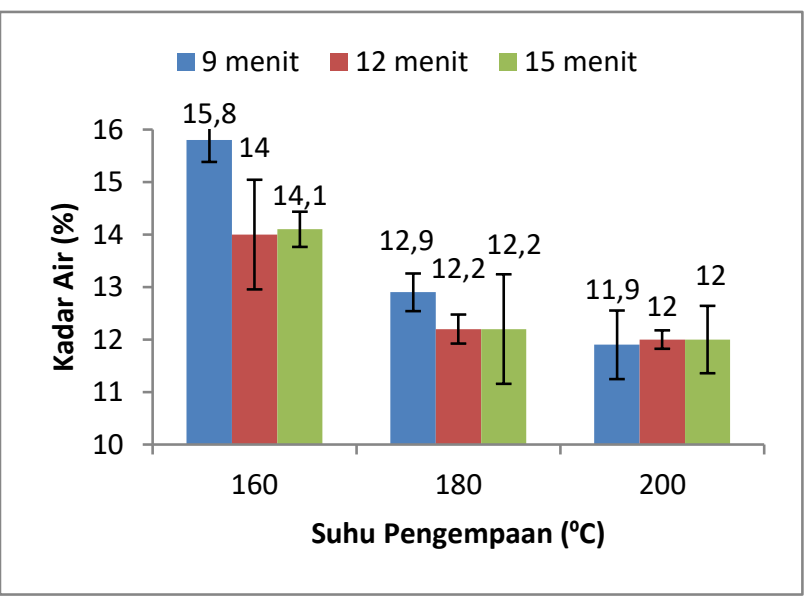

Gambar 1. Kadar air papan partikel sengon berperekat kitosan yang diproduksi pada suhu dan lama kempa berbeda.

Gambar 1 menunjukkan bahwa nilai kadar air terendah pada suhu pengempaan $200^{\circ} \mathrm{C}$ dengan waktu kempa 9 menit. Sementara kadar air tertinggi pada suhu kempa $160^{\circ} \mathrm{C}$ dengan lama pengempaan 9 menit. Hasil analisis ragam menunjukkkan bahwa suhu dan waktu pengempaan berpengaruh nyata terhadap kadar air papan. Sementara interaksi antara keduanya tidak berpengaruh nyata. Suhu $160^{\circ} \mathrm{C}$ menghasilkan kadar air yang lebih tinggi dibandingkan dengan suhu $180^{\circ} \mathrm{C}$ dan $200^{\circ} \mathrm{C}$. Sedangkan suhu $180^{\circ} \mathrm{C}$ dan $200^{\circ} \mathrm{C}$ menghasilkan kadar air yang relatif sama. Suhu $180^{\circ} \mathrm{C}$ dengan waktu kempa yang berbeda-beda diperoleh kadar air papan yang relatif sama, begitupula dengan suhu kempa $200^{\circ} \mathrm{C}$.

Nilai kadar air memenuhi $\mathrm{JIS}$ pada suhu $180^{\circ} \mathrm{C}$ dan $200^{\circ} \mathrm{C}$ yang mensyaratkan kadar air papan $5-13 \%$.
Sementara hanya papan dengan waktu kempa 9 menit pada suhu $160^{\circ} \mathrm{C}$ yang tidak memenuhi SNI yang mensyaratkan kadar air maksimal 14\%. Besarnya kandungan air dipengaruhi oleh kadar air bahan baku (Fauziah et al., 2014). Selain itu sifat partikel kayu yang higroskopis dan perekat yang juga bersifat menyerap air sehingga kadar air papan menjadi meningkat (Dompeipen et al., 2016). Kadar air juga dipengaruhi oleh jumlah air yang menguap selama proses pengempaan dan kandungan air dalam perekat.

\section{Kerapatan}

Hasil pengujian kerapatan dapat dilihat pada Gambar 2 yang menyajikan hubungan antara suhu dan waktu pengempaan terhadap kerapatan. Kerapatan papan berkisar antara $0,74 \mathrm{~g} / \mathrm{cm}^{3}-0,84 \mathrm{~g} / \mathrm{cm}^{3}$.

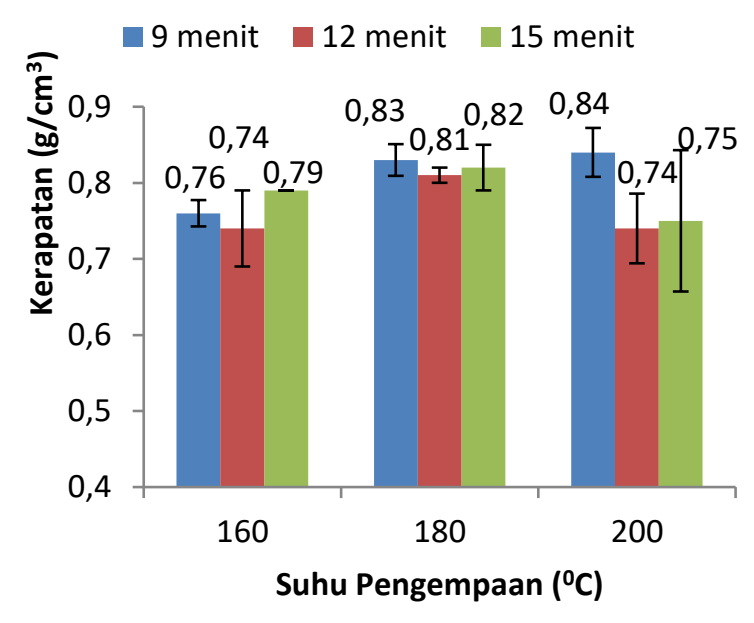

Gambar 2. Kerapatan papan partikel sengon berperekat kitosan yang diproduksi pada suhu dan lama kempa berbeda

Kerapatan papan terendah pada suhu kempa $160^{\circ} \mathrm{C}$ dan $200^{\circ} \mathrm{C}$ dengan waktu kempa 12 menit. Kerapatan tertinggi pada suhu kempa $200^{\circ} \mathrm{C}$ dengan waktu kempa 9 menit. Tabel sidik ragam menunjukkan bahwa waktu kempa tidak berpengaruh nyata terhadap kerapatan papan sedangkan suhu kempa berpengaruh nyata terhadap kerapatan papan. Interaksi antara kedua perlakuan tidak berpengaruh nyata terhadap kerapatan papan Hasil uji lanjut berganda Duncan menunjukkan bahwa suhu kempa $160^{\circ} \mathrm{C}$ dan $200^{\circ} \mathrm{C}$ memiliki kerapatan yang relatif sama. Namun pada suhu $180^{\circ} \mathrm{C}$ diperoleh nilai kerapatan papan yang lebih tinggi.

Berdasarkan JIS dan SNI semua papan memenuhi standar. JIS mensyaratkan kerapatan papan $0,5 \mathrm{~g} / \mathrm{cm}^{3}-0,9$ $\mathrm{g} / \mathrm{cm}^{3}$ dan SNI 0,4 g/cm $3-0,9 \mathrm{~g} / \mathrm{cm}^{3}$. Namun hanya suhu $200^{\circ} \mathrm{C}$ dengan waktu kempa 15 menit yang memenuhi kerapatan target yaitu $0,75 \mathrm{~g} / \mathrm{cm}^{3}$. Tidak meratanya penyebaran partikel dan perekat pada saat pencampuran menyebabkan nilai kerapatan yang bervariatif (Setiawan, 2004). 


\section{Daya Serap Air}

Hubungan antara waktu kempa dan suhu kempa terhadap daya serap air papan partikel disajikan dalam Gambar 3. Daya serap air berkisar antara $66,24-87,85 \%$.

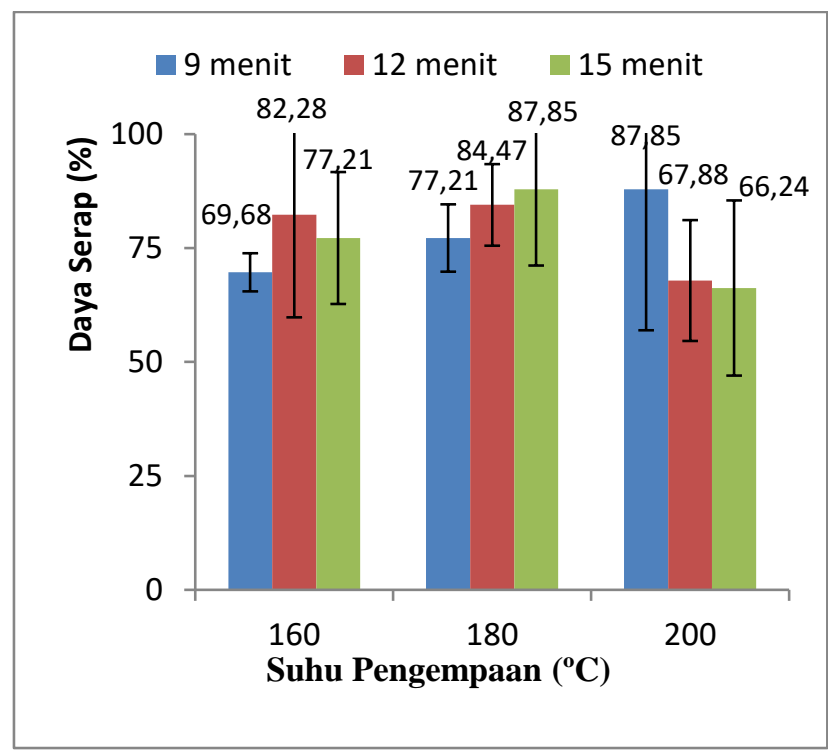

Gambar 3. Daya serap air papan partikel sengon berperekat kitosan yang diproduksi pada suhu dan lama kempa berbeda

Daya serap air tertinggi terdapat pada waktu kempa 15 menit dan suhu kempa $180^{\circ} \mathrm{C}$ sementara daya serap air terendah pada waktu kempa 15 menit dengan suhu $200^{\circ} \mathrm{C}$. Tabel sidik ragam menunjukkan bahwa suhu dan waktu kempa tidak berpengaruh nyata terhadap daya serap air papan partikel. Daya serap air tidak disyaratkan dalan JIS maupun SNI.

Daya serap air yang tinggi erat kaitannya dengan bahan yang digunakan yang bersifat hidroskopis. Hasil ini sesuai dengan penelitian Sudiryanto (2015) dimana semakin lama waktu pengempaan daya serap air berkurang. Selain itu, suhu kempa yang tinggi menyebabkan perekat menjadi matang sehingga ikatan antar partikel semakin kuat dan kemampuan menyerap air rendah. Tidak adanya kecenderungan daya serap air karena penyebaran perekat yang kurang merata pada beberapa papan.

\section{Pengembangan Tebal}

Hasil pengujian papan partikel dengan perekat kitosan menunjukkan pengembangan tebal berkisar antara $6,75-20,06 \%$. Nilai pengembangan tebal disajikan pada Gambar 4.

Gambar 4 menunjukkan hubungan antara suhu dan waktu kempa terlihat nilai pengembangan tebal tertinggi pada suhu kempa $180^{\circ} \mathrm{C}$ dengan lama pengempaan 9 menit. Sementara pengembangan tebal terendah pada waktu kempa 9 menit dengan suhu $160^{\circ} \mathrm{C}$. Semakin lama waktu pengempaan pengembangan tebal meningkat pada suhu kempa $160^{\circ} \mathrm{C}$. Berbanding terbalik dengan suhu kempa $180^{\circ} \mathrm{C}$ dan $200^{\circ} \mathrm{C}$ yang mengalami penurunan pengembangan tebal seiring bertambahnya waktu pengempaan. Pengembangan tebal berbanding lurus dengan daya serap air. Meskipun demikian, tebal papan yang berbeda-beda menyebabkan nilai pengembangan tebalnya tidak menunjukkan tren yang sama. Selain itu, kandungan air atau kadar air papan mempengaruhi pengembangan tebal. Kadar air yang tinggi cenderung menurunkan nilai pengembangan tebal papan.

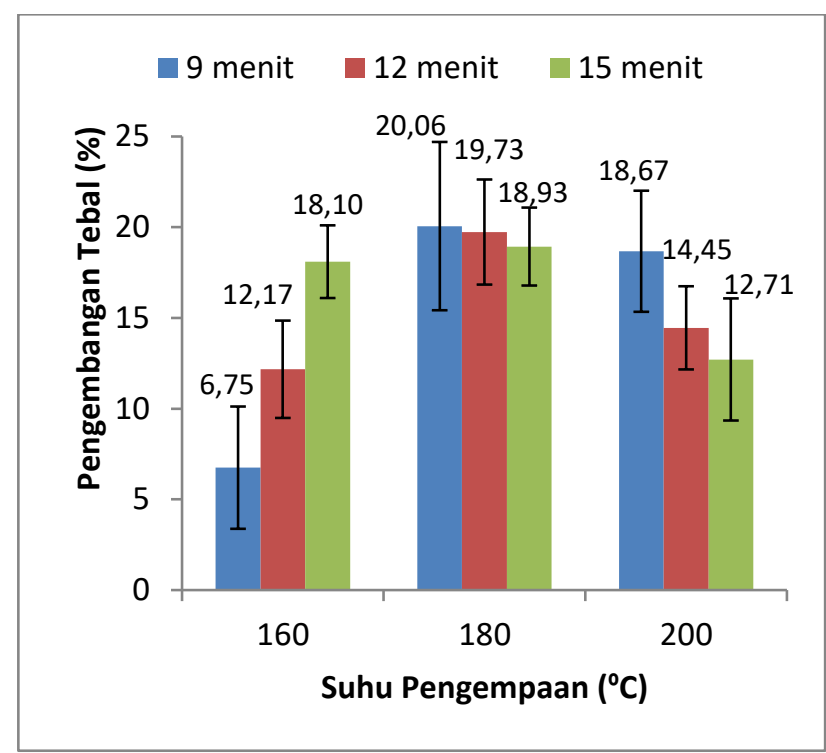

Gambar 4. Pengembangan tebal papan partikel sengon berperekat kitosan yang diproduksi pada suhu dan lama kempa berbeda

Hasil analisis ragam menunjukkan bahwa waktu kempa tidak berpengaruh nyata terhadap pengembangan tebal papan. Namun suhu kempa berpengaruh nyata pada terhadap nilai pengembangan tebal. Begitupula interaksi antara waktu kempa dan suhu kempa berdasarkan tabel sidik ragam berpengaruh nyata terhadap pengembangan tebal.

Hasil pengujian yang dibandingkan dengan JIS A 5908-2003 yang mensyaratkan pengembangan tebal maksimal $12 \%$ menyebabkan papan partikel yang dihasilkan tidak seluruhnya memenuhi standar. Begitupula jika dibandingkan dengan SNI.

Pengembangan tebal papan partikel dipengaruhi oleh partikel kayu sengon yang memiliki kerapatan rendah sehingga pengembangan tebalnya cukup tinggi (Sudiryanto, 2015). Pengembangan tebal dapat menjadi salah satu indikator penggunaan papan yang dihasilkan. Pengembangan tebal yang tinggi menandakan stabilitas papan yang rendah sehingga tidak dapat diaplikasikan untuk bagian eksterior dalam jangka waktu yang panjang.

\section{Keteguhan Patah (MOR)}

Nilai MOR papan partikel dari penelitian ini berkisar antara $82,82 \mathrm{~kg} / \mathrm{cm}^{2}-145,65 \mathrm{~kg} / \mathrm{cm}^{2}$. Nilai MOR ditunjukkan 
pada Gambar 5 serta hubungan antara suhu dan waktu pengempaan papan partikel.

Nilai MOR tertinggi terdapat pada suhu kempa $200^{\circ} \mathrm{C}$ dan waktu kempa 12 menit sebesar $145,65 \mathrm{~kg} / \mathrm{cm}^{2}$. Sementara nilai MOR terendah yaitu $82,82 \mathrm{~kg} / \mathrm{cm}^{2}$ dengan suhu kempa $180^{\circ} \mathrm{C}$ dan waktu kempa 9 menit. Hasil analisis ragam menunjukkan bahwa suhu kempa berpengaruh nyata terhadap nilai MOR. Sementara lama pengempaan dan interaksinya tidak berpengaruh nyata.

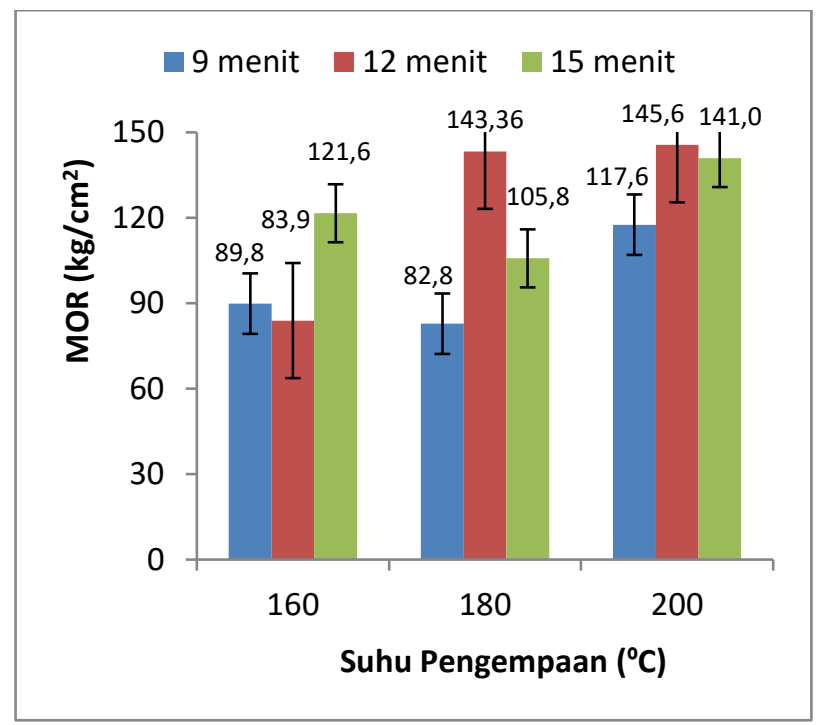

Gambar 5. Keteguhan Patah (MOR) papan partikel sengon berperekat kitosan yang diproduksi pada suhu dan lama kempa berbeda

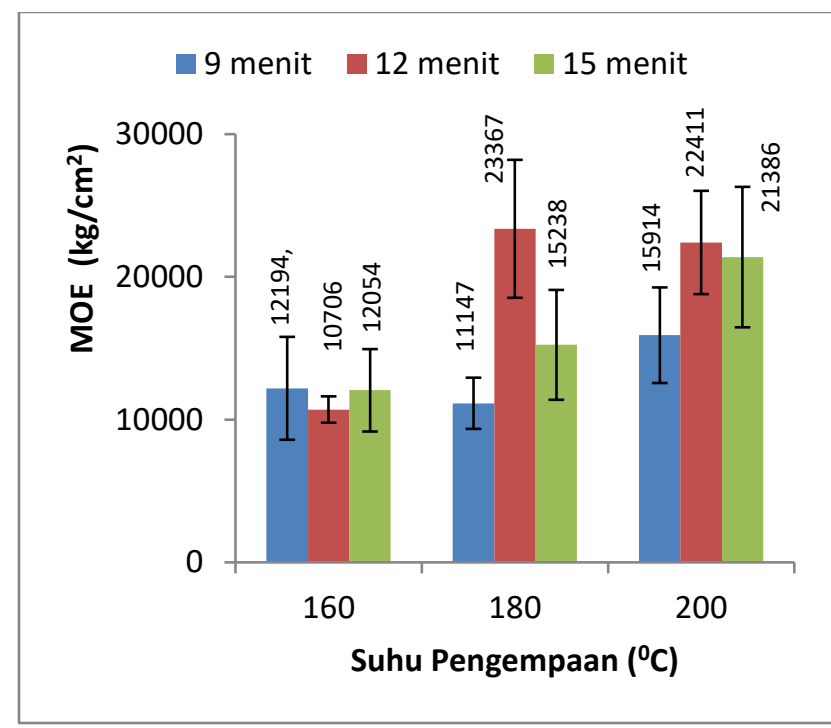

Gambar 6. Modulus elastisitas (MOE) papan partikel sengon berperekat kitosan yang diproduksi pada suhu dan lama kempa berbeda

Nilai MOR papan partikel dengan perekat kitosan yang menggunakan suhu dan waktu kempa yang berbedabeda telah memenuhi JIS A 5908-2003 dan SNI yang mensyaratkan minimal $82 \mathrm{~kg} / \mathrm{cm}^{2}$. Nilai MOR yang cukup tinggi berkaitan dengan bahan yang digunakan yaitu kerapatan rendah sesuai dengan pernyataan Shmulsky dan Jones (2011) yaitu semakin rendah kerapatan kayu semakin tinggi pula kekuatan papan partikel yang dihasilkan.

\section{Modulus Elastisitas}

Keteguhan lentur merupakan suatu kemampuan benda/papan untuk kembali ke bentuk semula apabila dikenai suatu gaya. Hasil pengujian MOE berkisar antara $10.706-23.367 \mathrm{~kg} / \mathrm{cm}^{2}$. Hubungan antara suhu dan waktu kempa terhadap nilai MOE papan partikel disajikan dalam Gambar 6.

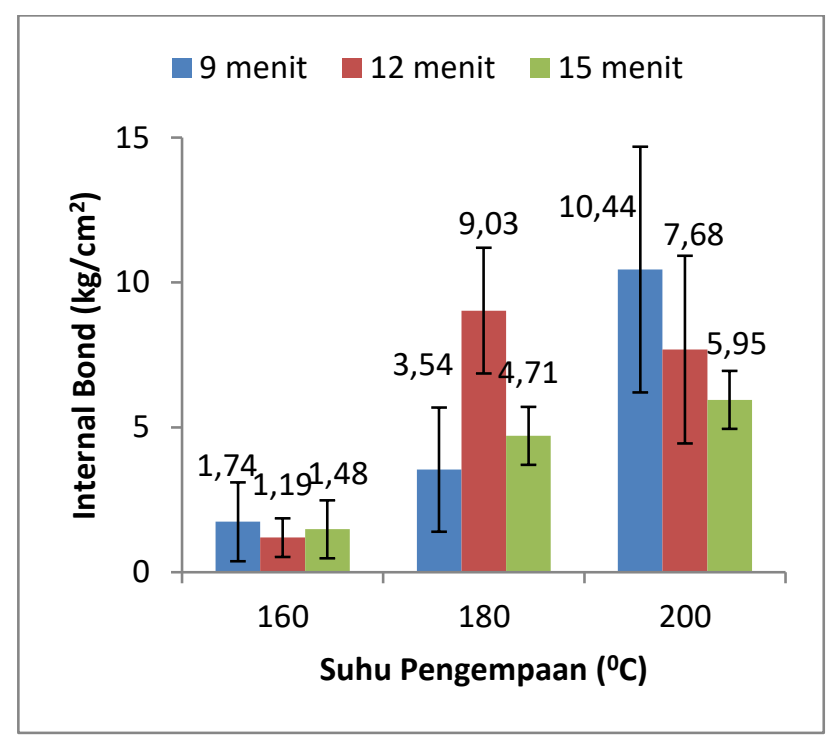

Gambar 7. Keteguhan rekat papan partikel sengon berperekat kitosan yang diproduksi pada suhu dan lama kempa berbeda

Gambar 6 menunjukkan bahwa nilai tertinggi terdapat pada suhu kempa $180^{\circ} \mathrm{C}$ dengan waktu kempa 12 menit yaitu $23.367 \mathrm{~kg} / \mathrm{cm}^{2}$. Sementara nilai terendah pada suhu kempa $160^{\circ} \mathrm{C}$ dengan waktu kempa 12 menit yaitu $10.706 \mathrm{~kg} / \mathrm{cm}^{2}$. Nilai MOE papan berbanding lurus dengan nilai MOR. Semakin tinggi nilai MOR semakin tinggi pula nilai MOE yang dihasilkan. Hal tersebut dapat kita lihat pada Gambar 8 dan Gambar 9 yaitu nilai MOE dan MOR. Tabel sidik ragam menunjukkan bahwa suhu kempa dan waktu kempa berpengaruh nyata terhadap keteguhan lentur papan. Interaksi antara suhu dan lama pengempaan juga berpengaruh nyata.

Secara umum papan partikel ini belum memenuhi JIS maupun SNI yang mensyaratkan nilai MOE minimal $20400 \mathrm{~kg} / \mathrm{cm}^{2}$. Tidak adanya pola tertentu pada hasil pengujian MOE disebabkan karena tidak meratanya perekat pada saat pembuatan papan.

\section{Keteguhan Rekat}

Keteguhan rekat papan partikel yang dihasilkan berkisar antara $1,19 \mathrm{~kg} / \mathrm{cm}^{2}$ sampai dengan $10,44 \mathrm{~kg} / \mathrm{cm}^{2}$. Nilai rata-rata keteguhan rekat disajikan pada Gambar 7. 
Gambar 7 menunjukkan bahwa nilai keteguhan rekat terendah pada suhu kempa $160^{\circ} \mathrm{C}$ dengan lama pengempaan 12 menit dengan nilai $1,19 \mathrm{~kg} / \mathrm{cm}^{2}$, sedangkan nilai tertinggi pada suhu kempa $200^{\circ} \mathrm{C}$ dengan lama pengempaan 9 menit yaitu $10,44 \mathrm{~kg} / \mathrm{cm}^{2}$. Pada lama pengempaan 9 dan 15 menit, seiring bertambahnya suhu kempa, keteguhan rekat cenderung meningkat, sedangkan lama pengempaan 12 menit tidak menunjukkan tren tertentu. Hasil analisis ragam menunjukkan bahwa suhu pengempaan berpengaruh nyata terhadap keteguhan rekat. Lama pengempaan dan interaksi antara keduanya tidak berpengaruh nyata terhadap keteguhan rekat papan.

Secara umum papan partikel telah memenuhi SNI dan JIS yang mensyartkan keteguhan rekat papan partikel minimal $1,5 \mathrm{~kg} / \mathrm{cm}^{2}$. Hanya suhu kempa $160^{\circ} \mathrm{C}$ dengan waktu kempa 12 dan 15 menit yang tidak memenuhi. Papan partikel dengan keteguhan rekat rendah cenderung mudah pecah. Keteguhan rekat dipengaruhi oleh suhu pengempaan, dimana perlu disesuaikan dengan perekat yang digunakan, apabila suhu terlalu rendah perekat tidak matang dan jika terlalu tinggi perekat menjadi over mature, sehingga mengurangi keteguhan rekat. Selain itu, degradasi komponen kimia yag berlebihan dapat menyebabkan penurunan sifat papan tersebut (Prayitno et al., 2008)

\section{KESIMPULAN}

Dari hasil penelitian menunjukkan bahwa perekat kitosan dari limbah kulit udang sangat layak dikembangkan. Karakteristik kitosan yang dihasilkan telah memenuhi Standar Protan Laboratory. Dilihat dari kualitas papan yang dihasilkan maka perekat kitosan sangat layak untuk dikembangkan sebagai perekat papan partikel. Hasil pengujian menunjukkan bahwa telah memenuhi SNI 032105-2006 maupun JIS A 5908:2003 untuk parameter kadar air, kerapatan, MOR, MOE, dan keteguhan rekat pada suhu kempa $180^{\circ}$ dengan waktu kempa 12 menit. Nilai kadar air $12,2 \%$, kerapatan $0,81 \mathrm{~g} / \mathrm{cm}^{3}$, daya serap air $84,47 \%$, pengembangan tebal $19,73 \%$, keteguhan patah $143,36 \mathrm{~kg} / \mathrm{cm}^{2}$, keteguhan lentur $23.367 \mathrm{~kg} / \mathrm{cm}^{2}$ dan keteguhan rekat $9,03 \mathrm{~kg} / \mathrm{cm}^{2}$.

\section{DAFTAR PUSTAKA}

Agustina, S., Swantara, I., \& Suartha, I. (2015). Isolasi kitin, karakterisasi, dan sintesis kitosan dari kulit udang. Jurnal Kimia, 9(2), 271-278.

Badan Standarisasi Nasional. (2006). SNI Papan Partikel (Nomor 032105-2006). Bogor: Badan Standarisasi Nasional.

Bowyer, J. L., R. Shmulsky, and J. G. Haygreen. (2003). Forest products and wood science: an introduction (4th ed.). lowa, USA: lowa State Press.

Dompeipen, E.J., Marni, K., \& Riadi, P.M. (2016). Isolasi kitin dan kitosan dari limbah kulit udang. Majalah BIAM, 12 (1): 32-38.

Fauziah, Wahyuni, D., \& Lapanporo, B.P. (2014). Analisis sifat fisik dan mekanik papan partikel berbahan dasar sekam padi. Positron, 4(2): $60-63$

Hossain, M.S., \& Iqbal, A.. (2014). Production and characterization of chitosan from chrimp waste. J. Bangladesh Agril. Univ., 12 (1): 153- 160.

Japanese Standards Association. (2003). Particleboards (JIS A 5908: 2003). Tokyo, Japan: Japanese Standards Association.

Kusumaningsih, T., Masykur, A., \& Arief, U. (2004). Pembuatan kitosan dari kitin cangkang bekicot. Jurnal Biofarmasi, 2(2): 64-68.

Prayitno, T.A., Widyorini, R., \& Rofii, M.N. (2008). Kualitas perekatan dua jenis kayu hutan rakyat dengan variasi perlakuan panas (Laporan Penelitian Tahun 2008). Retrived from https://repository.ugm.ac.id/96969/1/Kualitas\%20Perekatan\% 20Dua\%20Jenis\%20Kayu\%20Hutan\%20Rakyat\%20Dengan \%20Variasi\%20Perlakuan\%20Panas.pdf

Roffael, E. (1993). Formaldehyde Release from Particle Board And Other Wood Based Panels. Kuala Lumpur, Malaysia: Forest Research Institute Malaysia.

Saputro A.N.C., Indriana K., \& Sutarno. (2009). Pengaruh metode isolasi terhadap sifat karakteristik kitosan. Prosiding Seminar Nasional Kimia dan Pendidikan Kimia 2009. Surakarta, 18 Maret 2009: Program Studi Pendidikan Kimia, Jurusan Matematika dan IImu Pengetahuan Alam, Fakultas Keguruan dan IImu Pendidikan, Univesitas Sebelas Maret Surakarta

Setiawan, C.N.B. (2004). Pemanfaatan tandan kosong kelapa sawit sebagai bahan baku perekat likuida kayu dan papan partikel berkerapatn sedang (Skripsi). Bogor: Fakultas Kehutanan Institut Pertanian Bogor.

Sudiryanto, G. (2015). Pengaruh suhu dan waktu pengempaan terhadap sifat fisik dan mekanik papan partikel kayu sengon (Paraserienthes falcatria). Jurnal DISPROTEK, 6 (1): 67-74. 